\title{
Swedish Archaeology in Perspective and the Possibility of Reflexivity
}

Åsa Berggren

\begin{abstract}
In exploring the possibilities of reflexivity in the Cultural Resource Management archaeology in Sweden, a comparison is made between the excavation at Catalhöyük in Turkey and an excavation at Burlöv in Malmö, Sweden. The former, a large-scale research project that aims at implementing post-processual ideas, differs in many ways from the latter, which is part of a large-scale rescue project, Öresundsförbindelsen. There are also similarities, and in different ways reflexivity seems to be achieved in both cases.
\end{abstract}

Asa Berggren, Institute of Archaeology, University of Lund, Sandgatan I, SE-223 50 Lund, Sweden.

Key words: methodology, reflexivity, CRM archaeology, Catalhöyük, Malmö.

\section{INTRODUCTION}

What is happening in Swedish archaeology today? Like everything else, the discipline of archaeology changes with a changing environment. It is affected by the changing demands from different groups in society, for example for political and economical reasons. We have seen several consequences of these demands in the last few years, for instance the large projects in Cultural Resource Management (CRM) archaeology in southern Sweden and the government bill stating that CRM archaeology should now be considered part of a research process.

How does the discipline itself change? In this article I would like to address this question by looking at one particular issue. In the development of methods used to bridge the gap between theory and practice, the reflexive method as described and implemented by Ian Hodder in Çatalhöyük, Turkey $(1997,1999,2000)$ stands out as an explicit example. But what is the situation like in Sweden? Are there prerequisites to implement the reflexive method here as well? Or has reflexivity already been introduced into Swedish archaeology, only without the explicit label?

\section{A DAY IN THE LIFE OF A SWEDISH ARCHAEOLOGIST AT ÇATALHÖYÜK, TURKEY. ${ }^{1}$ \\ It is seven o'clock in the morning and I hear the whistle blow outside in the front yard. It means the workday has begun and the workmen and workwomen from the nearby}

\footnotetext{
1 The events described in the text are a combination of typical activities on site at Catalhöyük during the seasons of 1998 and 1999.
} 
town Cumra and the village Küçükköy have arrived at the site. I cross the yard, past the different specialists' labs, and walk into the dig room where we keep our equipment. I and my colleagues bring what will be needed during the day and walk up the mound. The night has been windy and we have to start by adjusting the shelter that keeps us and the Neolithic building we are excavating out of the hot Turkish sun.

There is much to be done today. During the morning I want to finish the unit I started yesterday, later the specialist tour is expected and in the afternoon the film team will come around. I am just removing a small amendment to an inside wall in a building. It looks as if it were put there as a support for the wall, perhaps when the wall threatened to collapse. I get down to "my" room by using a ladder. We are excavating about a meter and a half below the present-day ground level. Above our building, another house has been removed in the preceding seasons. I start to fill a bucket with soil from the support of the wall. I am using my trowel, and as I get closer to the floor or wall, I use a leaf trowel to remove the soil. One of the Turkish workmen is sieving the soil from our different spaces in the building, a few meters from the trench. He separates the finds in the plastic bags; one for clay objects, one for charcoal, one for bones and so on. Sometimes it is difficult to communicate with the local people working on the excavation as they speak very little English, and it is not required within the project that we speak Turkish. The influence of the local people on the excavation is therefore limited.

As I remove the soil I find some unusual artefacts lying on the floor placed under the supporting wall. A couple of horn cores still attached to a small piece of the skull lie with the tips almost touching the original wall, with a clay ball placed right in the middle of the horns, pushed somewhat down into the floor. Next to this constellation are more animal bones and some flakes of obsidian. Were they placed here intentionally or did they just happen to be here when the supporting wall was built? I leave the artefacts in place as I see the group of specialists approaching our tent. It is quite a large group, perhaps about ten people including the animal bone and human bone specialists, the botany people, the flint and the obsidian specialists, the clay ball person and the figurine specialist, among others. They gather around our trench supervisor as he tells them about our progress since their last visit a few days ago. Then it is their turn to walk around to the different spaces in the building and give us feedback on previously excavated units. On the last visit by the specialists, we decided which units should be prioritised and analysed immediately. Now the results are presented and discussed in the trench. The turn has come to my space, the room I have been excavating for the last couple of weeks. We talk about a continuation of the supporting wall that I removed a few days ago. It turns out to be an interesting unit as the bone team has found an extraordinary large amount of small animal bones in the soil sample processed. How did they get there? We discuss several alternatives of how to interpret this find. Could the bones have come here together with the material in the supporting wall when it was built? Or was the building deserted at some point before the supporting wall was built, during which time mice and other small animals lived and died here? Or are the bones remains of owl pellets? In that case, did birds have access to the 


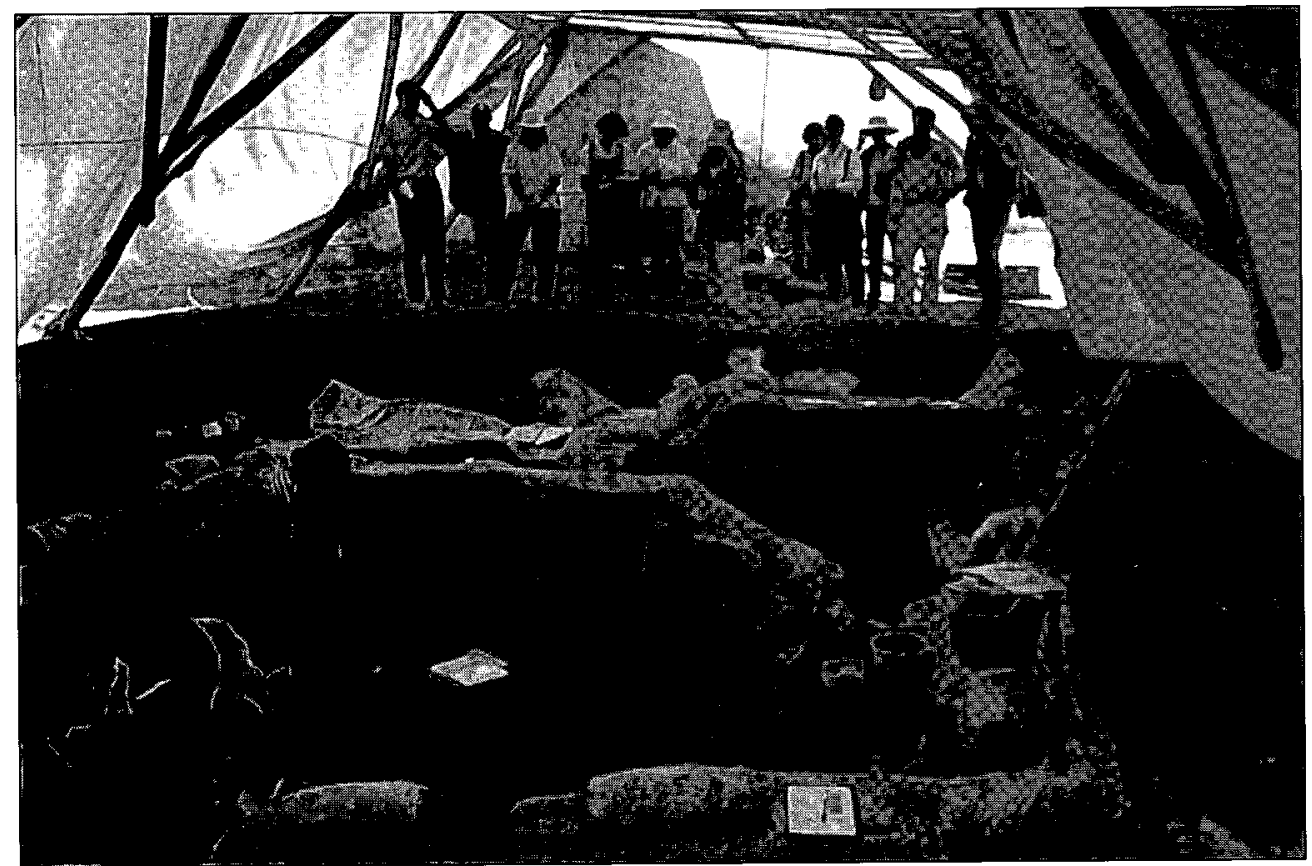

Fig. 1. A specialists' visit in the trench at Catalhöyük. Photo: Asa Berggren.

building during the time of desertion? The archaeobotany team has found only small amounts of charred seeds and plant remains, which might suggest that the material in the wall was collected some distance away from the settlement and brought to the site as building material. Could the animal bones have been a part of this material? The different alternatives are discussed at length, but there is no concluding decision on the most likely interpretation at this time. We need more information. When it is time to decide which units should be given priority for the next tour, we go on to look at the new finds of today, namely the artefacts beneath the rest of the wall. One of the animal bone specialists can tell me right away that this is a sheep horn core, which is interesting as I have found several other sheep horn cores in the same room before. Some of the other bones lying next to it are also from sheep. We decide to prioritise the rest of the supporting wall as well. I have seen more small animal bones while digging, so a comparison between the two might be fruitful. The group of specialists hurry on to the next trench where the American team is excavating, while I try to memorise what has been said during today's discussion.

I discuss the finds from my room with one of my colleagues. She has found similar bones from small animals in the main space of our building. Could it be that the whole house was deserted at one point? I remove the rest of the unit before lunch-break. As most of the soil goes into the samples, not much is left for dry sieving. I plan and photograph the finds on the floor before lifting them. The clay ball seems to be intact and I put it in an envelope while being careful not to touch it with my hands, as it may 
be sampled for chemical residue analysis later. Finally it is lunch-time and the whole team sits down to a hot meal in the dining room. A TV crew from Britain are visiting the site today and are having lunch together with the director. He will take them around the site later. The site is visited by many people during the season. Tourists, local schools, journalists, and others all receive a varying degree of attention when they arrive at the site. Some are shown around by the locally employed guides, others are given the grand tour by the director.

After lunch I give a short résumé of this morning's discussion with the specialist team while being filmed. I hope I remember everything correctly. This will be a short clip, only a couple of minutes. As the film person hurries away to the next trench, following the footsteps of the specialists' tour, I have to start thinking about the next unit to be lifted in my room. It's the floor, and it involves extensive sampling. I will only remove the very top as it seems to be very thin. In places the white plaster is preserved, as in the corners and underneath the now removed supporting walls. Apart from the normal soil samples, which include material to be dry sieved and material to be stored in an archive for future analysis, the floor will also be sampled for chemical analysis, phytolith analysis and a variety of other analyses. It is very time consuming, and some of the samples will not be processed until the season is over, but the results that do get back to the excavator during excavation make it worth the time and effort.

After the afternoon tea-break, paperwork and work in front of the computer screen await most of us. The excavation is finished for the day. Some get special permission from the Turkish government representatives stationed on site, to go back up to the mound to finish excavating some specially important or delicate features. The excavation is closely monitored and regulated by the local authorities. Two representatives are stationed on site during the season, keeping a close watch at the operation.

I go to the dig room to finish filling in some unit sheets and write my diary on one of the laptop computers we share. In the diary I try to give a description in my own words of what has happened in my space during the last few days, since I made my last entry. I discuss the finds under the supporting wall. How did they get there? My impression is that some of them were carefully laid out and that the horn core represents something special. The small animal bones found behind the wall still puzzle me. Had the building been infested at some point? Putting everything into a wider context, I have the opportunity to write down more of my thoughts about sequences etc. in the diary, than I do on the unit sheets.

The routine of the day, as on any other day, continues as we all go to dinner at seven o'clock as the sun is setting behind the mountains on the border of the plain surrounding us. And as on any other night, people gather on the veranda before going to bed. 


\section{AND A DAY IN THE LIFE OF THE SAME ARCHAEOLOGIST IN MALMÖ ${ }^{2}$}

It is seven o'clock in the morning and we arrive at the site by car. We park next to our cabins and quickly change into our work clothes. We are removing topsoil in one area, so a machine excavator and a few dumper trucks are waiting for us while others are already busy around our trench moving large volumes of soil. The building of the motorway, which is the reason for the large archaeological project we are a part of, has already started. This situation overshadows most others as it directly affects many aspects of work on the excavation. We have to plan the progress of our work according to the needs of the builders and their suppliers. As these needs seem to be shifting, there is constant discussion about the accessibility of different areas. This morning we notice that a part of the western area is marked by poles. After a quick discussion in the cabin, we decide who will work next to the machine excavator that is stripping the topsoil and who will survey the already stripped areas with the total station. We usually take turns doing these activities as they can be monotonous if done by one person every day.

After that I have to deal with the new poles. They turn out to be the outline of a small work road needed by the motorway builders. They need to transport soil and building material across the area and they are wondering when we are finished digging so they can have access to this specific area. Can we be finished by Friday? As we haven't even started excavating in that area it is not a convenient solution for us, and after some discussion we all agree that the transports have to take place somewhere else. This is a recurring situation, as the excavation area is situated between building areas. Soil and building material have to be transported somewhere and it would have been logical to use the stretch of the future road. Instead a compromise has been reached. A temporary road has been laid out in the fields just outside the building area, at one point crossing our excavation area. But sometimes this is not sufficient for the builders and the discussion of accessibility has to be brought up again, just as this morning.

The rest of the team are working in their different areas, where they are responsible for prioritisation and excavation. We have divided the excavation into smaller areas according to topography and features. I walk down to my colleagues who are working in an area consisting of a slope down to a wet area just north of the site. They have just finished excavating two round features that we thought resembled Mesolithic huts when they were first exposed. Now they look a bit different. They seem to be too irregular to be the remains of huts and there are no finds in the fills to give us a clue as to what the features represent. Instead we discuss an alternative interpretation as treefall features.

Working in pairs in each area provides an opportunity to discuss priority and interpretation, unlike when working one by one. Being pressured by a tight schedule,

\footnotetext{
${ }^{2}$ The events described in the text are a combination of typical activities on the excavation at Burlöv $20 \mathrm{C}$ in 1998 where I functioned as a supervisor. The excavation was part of the project Öresundsförbindelsen, consisting of about 20 excavations conducted by the then called Department of Antiquities, Malmö, during 1996-98.
} 
not every single dark spot in the moraine clay can be investigated. This would not be a desirable situation anyway, as excavating all of them would not necessarily increase our knowledge of the activities that has taken place at this Bronze Age/pre-Roman Iron Age settlement. In each area it has to be decided what to excavate and what to leave with little or without any investigation. This is done according to some major issues decided on by the project management, in order to facilitate the answering of some specific questions. One principle we have agreed on at this excavation is to try to focus on that which is diffuse and difficult to categorise. If there is a number of similar, well-known features, for example wells, we have decided to excavate only a portion of them carefully and to use the excavating machine for investigating the rest. Instead we concentrate on the features we do not recognise and that are difficult to understand. In this way we hope to illuminate new, or less known, aspects of a settlement such as this.

In the area next to the tree-fall features there are many vague and irregular colourings in the clay, some containing charcoal, but hardly any finds to give us an idea of their formation process. Could they represent the remains of paths of animals or humans moving around the settlement or are they just the traces of flowing water? My colleagues have decided to take soil samples for later analysis, hoping this will give us some information. The storage place is filling up with samples, and we have to remember to empty it later. Many samples are taken, but not all of them will be analysed in the end. We may find something in post-excavation work that changes our idea of some features and additional samples may then be needed.

At lunch-time we gather in the cabin to eat. There are twelve of us here today, and it is crowded around the table. Someone has noticed that a big dumper truck has taken

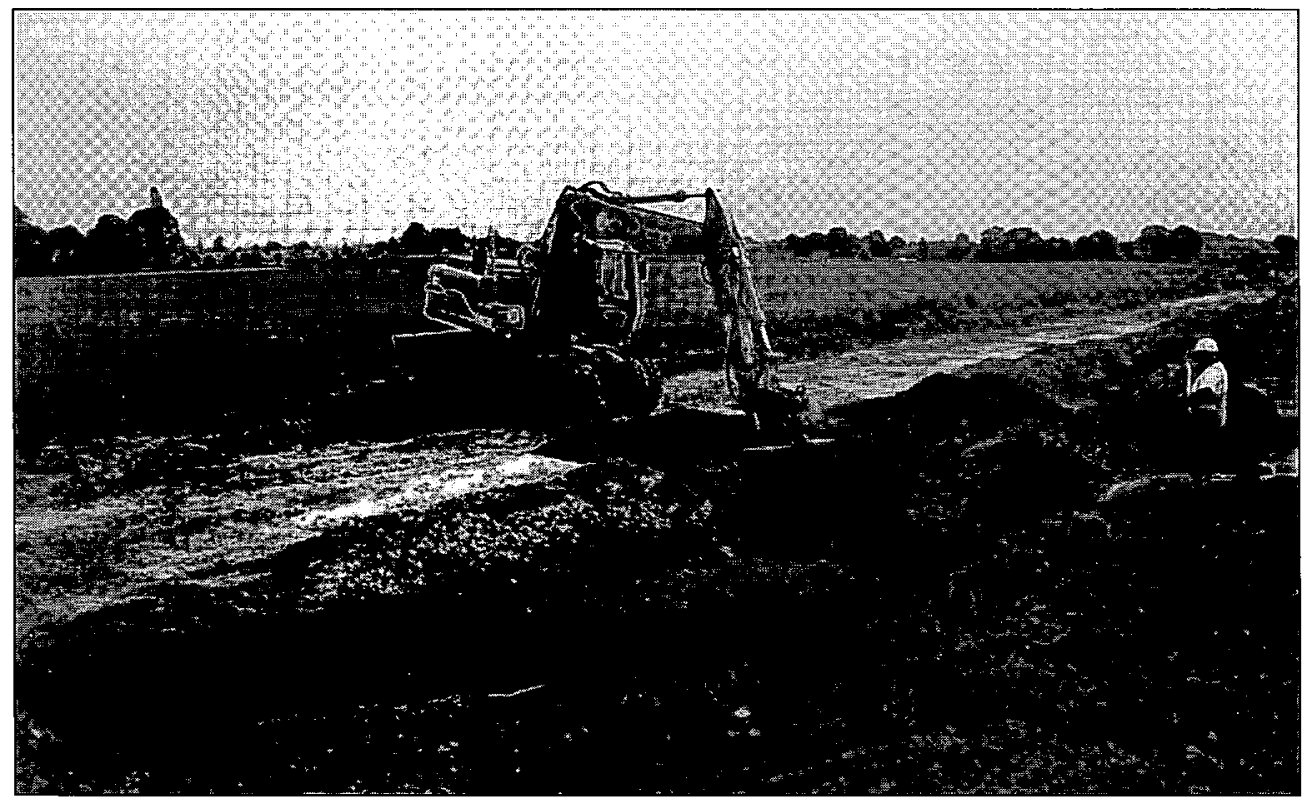

Fig. 2. Removing topsoil in Burlöv. Malmö. Photo: Ulf Celin. 
a shortcut over the very northern part of our area and destroyed some of the features there. The discussion is lively and we are all upset because this is not the first time something like this happens. Maybe we have to restrict access to our area by using some kind of barrier. Different alternatives are discussed and we decide to talk to our contact person among the builders.

In the office cabin we have two laptop computers and after lunch I want to check the plans from yesterday but both computers are busy at the moment. Every feature is registered after being investigated, and this is done directly by the person who excavated the feature. This leads to a somewhat heterogeneous terminology but there is a central decision on some of the most common terms in the database, which we intend to follow.

Instead of waiting for the computers, I take a walk to all the different areas and discuss the work in progress with my colleagues. The two people excavating in the area on top of the hill are digging a well. It seems to have some worked wood at the bottom and we decide to phone the conservators at the museum and ask them to take care of the wood. A pre-Roman house seems to be longer than we first thought, and a stone packing at the east end can be a clue to a special function of the building. Where the top soil is being stripped, we have found some hearths that look like they are grouped together. Could they be of the same age, or have they accumulated in this particular area? We decide to excavate all of them to look for datable finds, and we will take charcoal samples to use for dating.

We are short of some supplies, so I have to remember to order new bags for samples and some small poles for marking features; the water tank needs refilling as well. We use the water for wet-sieving and as the ground consists of clay we use a lot of water. I complain to myself that most of my time is consumed by logistics like this and the time I can spend on real archaeology seems too little. I sigh as I notice that the toilet needs emptying as well.

At the end of the afternoon the person surveying features with the total station is finished and we make the transition in the computer to a CAD program and today's work becomes visible on the screen. It looks as if there is some sort of structure in a group of postholes, which we haven't seen before. Getting an overview picture of all the features can sometimes help us to see more diffuse structures, such as this. Perhaps it is a building or a fence? We will take a closer look at this particular area tomorrow. But now the work day is done and it is nice to leave our muddy work clothes in the cabin as we leave the site and go home.

\section{A REFLEXIVE EXPERIMENT AND ITS IMPLEMENTATION}

One of the many differences between the two examples above is the explicit attempt to facilitate reflexivity at the excavation in Çatalhöyük. The site in central Turkey was first discovered and excavated by James Mellaart in the 1960s. It soon became well known for its early datings of agriculture and the spectacular finds of wall paintings in the well-preserved buildings. It was interpreted as a unique Early Neolithic city, run by a priesthood that worshipped a Mother Goddess. The site was reopened in the 
1990 s by Professor Ian Hodder in a new project. The project has received much attention, both because of the spectacular site itself and because of the ideas behind the methods employed at the excavation. It will undoubtedly be of considerable importance for the development of methodology in archaeology in general, even though the conditions at Çatalhöyük are quite extraordinary and far from the more "normal" archaeology that most of us are engaged in. The new excavations have also resulted in more varied interpretations of the site than was previously the case, and they are of great importance for the understanding of the Neolithic in the region.

One aim of the project is to implement post-processual ideas and work out a methodology for post-processual fieldwork. Here only a short description of this methodology and the methods will be given, as they are described at length elsewhere (Hodder 1997, 1999, 2000). Hodder calls it a reflexive method, and by doing so he emphasises the main point of the method, which is to promote reflection at every step of the process of creating archaeological interpretations. The excavator is emphasised as playing an important role in forming the interpretations, which is in line with the post-processual focus on the subjective. This is not a new idea, but what can be seen as a new approach in Hodder's reflexive method is the explicit attempt to document this subjective trait. The field methods are therefore aimed at documenting what may influence the archaeological interpretations, for example the preconceptions and assumptions of the excavating staff. The underlying goal is to create a non-dichotomous way of thinking, which will break down barriers both among the disciplines and among the categories used in archaeology. The methodology is based on two main ideas, namely that in archaeology there is no production of objective facts and that no interpretation is to have pre-eminence over another. These ideas are translated into four main themes: reflexivity, contextuality, interactivity and multivocality (Hodder 1999, 2000). These somewhat abstract terms are transformed into practice in the system of work at Çatalhöyük.

The reflexivity, which in my opinion is the most important of the four themes, is acquired by facilitating reflection at every step of the process of interpretation. This process includes everything from deciding why and what to excavate to the actual digging. "Interpretation at the trowel's edge", as Hodder (1999:92) calls it. I think the most obvious method of accomplishing this reflexivity is to enable discussions between the excavating field staff and the various specialists working on the material while the excavation is underway, and in this manner influence the way the material is perceived and investigated. Another method is to make it possible for the excavator to express thoughts in a more narrative fashion, which is difficult to do in a limited context- or unit sheet. This is achieved both in the video clips and in the diary. These methods are also closely linked to the other themes as well as to reflexivity.

I regard the breaking down of barriers and the questioning of categories as one of the major prerequisites for facilitating reflexivity. In order to avoid an archaeology that only confirms what we already think we know, we need to question previous conclusions and interpretations. This will probably not be achieved by working in the same way as we always have, and applying certain methods just because they have 
been used before in similar situations. That is why the questioning of old interpretations and categories is important. In this way we may avoid the routinisation of the archaeological work.

In my point of view there are still some adjustments and developments needed before the whole methodology at Çatalhöyük is successful in achieving reflexivity. Of course, developing a new methodology takes time and it can hardly be completed right away. As this is a long term project, there is time. Parts of the methodology and its consequences have been criticised, for example the unequal relationship between specialists and excavating staff, and they have been vividly argued and discussed on site. The view of some of the field staff working on the project has been published in the volume dealing with the methodology of the project (Farid 2000). As this is an ongoing process, changes and compromises have been made, and some of the initial problems have now been dealt with and solutions have been reached. I have discussed some of these problems elsewhere (Berggren 2000). My main objections concern some structural problems of the project. Its large scale, structural inertia and traditional hierarchy have counteracted some of the goals of the reflexive method, mainly the reflexivity. With a large group of people involved (e.g. in the 1998 season there could be up to 100 persons present on site at one time), the need of a formalised system for organising work on the site is evident. The individual participant has his or her place in this system, and not many have a view of the larger picture. The specialists, like the excavating teams, participate with their own questions and objectives. This results in a large and heterogeneous group of people. The fact that the participants come from different archaeological traditions adds to this diversity. The discussions that arise from this diversity are very fruitful, which is of course one of the objectives. But instead of leading to the questioning of old categories and finding new ways of thinking, the large scale of the project has led to a degree of inflexibility and to everything and everyone falling into old and familiar patterns. The power of traditional structure and routine is strong and influences most archaeological work. In this case it has led to an informal hierarchical order where the specialists' questions seem to be of greater importance than those of the excavating staff, and the latter are reduced to providers of information that help the specialists answer their questions.

But it looks as if the reflexive method works better in a small-scale excavation and a less hierarchical environment. This became evident during the season of 1999 at Çatalhöyük, when a smaller group of about 20 archaeologists were working together with a small staff of specialists. They were involved in the excavation for a longer period of time; six months instead of the usual two-month season. The excavating staff was a more homogeneous group, mainly experienced British archaeologists. During this long season the field staff and the specialists had time to acquire a greater understanding of the material and the site, and there was more opportunity to reflect on different issues. With a smaller group of specialists, fewer compromises had to be reached (personal communication, Craig Cessford, area supervisor in the Çatalhöyük project). 


\section{DIFFERENCES AND SIMILARITIES}

A comparison of the excavations in Çatalhöyük and Malmö reveals striking differences but also similarities. But there are also differences and similarities within the projects, especially in a multinational team as at Çatalhöyük.

One of the thoughts following me throughout my participation in the project in Turkey has concerned the question of nationality. How much of the problems as well as the success of the project in Çatalhöyük is due to the mixture of nationalities and archaeological traditions? One of the four cornerstones of the methodology is multivocality, a principle which encourages and equates different viewpoints and which should benefit from this diversity. But the example above of the long season being more successful at achieving reflexivity is certainly thought provoking. Was this a result of the team being mainly from one country, or were other factors more significant for the outcome? The project as a whole has a multinational staff, and one of the reasons is of course to gain from this diversity, not to make work difficult. The fact that a more homogeneous group of archaeologists, with similar backgrounds and training in the same archaeological tradition, had greater success in achieving reflexivity leads to the question of whether a multinational team with cultural differences and language difficulties has less opportunity to achieve the same. I think that is not entirely the case, even though a certain level of mutual understanding and common ground naturally are required. The different results in achieving reflexivity at Çatalhöyük could have more to do with the different sizes of the teams and the time periods involved. I would like to think that the team during the long season was more successful because the season was longer and the group was smaller, not because it was more homogeneous.

However, nationality is clearly a factor that influences archaeological work. An international project gives us the opportunity to observe differences and to think about what characterises the different nationalities. Although situated in Turkey, the Catalhöyük project is run by British archaeologists and dominated by a British way of thinking about archaeology. This is of course not a homogeneous tradition but a mixture of all the participants' different backgrounds, from universities, museums and archaeological units. The project is therefore coloured both by the academic background of the aim of the project as well as by the practical set up, following ideas developed in British Cultural Resource Management archaeology. That means there is an element of CRM archaeology in this project, while the aim to implement post-processual ideas is part of an academic research tradition. CRM archaeology and research archaeology stem from two separate traditions that have had few (or no) aims in common (see the discussion below). This situation seems to cut across national differences and may be the cause of some of the difficulties in implementing the reflexive methodology.

How much of my experience of the project is due to my nationality? The fact that I am a Swedish archaeologist trained at a Swedish university with most of my archaeological experience from Swedish CRM, has most probably influenced the way I have experienced working on the project. It is certainly a different experience to work on the fantastic material at Catalhöyük, and when comparing it to the ancient remains in Sweden, the most evident difference is the nature and the state of preservation of the 
remains. But that is an aspect that goes beyond the scope of this article.

So what is it like for a Swedish archaeologist to work on a British project in Turkey? Apart from the more general aspects like the state of the remains, the climate and the language, which obviously are different from the situation in Sweden, there are also other differences that are evident. As seen in the two examples above of a normal day on a research excavation in Turkey and a CRM excavation in Sweden, the situation differs greatly. And the major difference that overshadows the others is the cause of the excavation. Since the Swedish example is a rescue excavation, the conditions are fundamentally different from the sponsor-financed research excavation in Turkey. As CRM archaeology is not ordered by but forced on the paying party, the cost is under constant debate while the quality, on the other hand, is discussed with and controlled by the authorities. This is of course not the case in Catalhöyük, where the financers the sponsors - are absent (apart from occasional visits). As they have chosen to pay, they do have opinions on the progress of work but also on the results, which is usually not the case in CRM archaeology. The presence of the builders at the site and the time pressure to finish quickly are vivid reminders of the reason why we are excavating within CRM archaeology. The remains of past activities will disappear very soon, and our task is to document and understand them. This kind of pressure is not present in Catalhöyük. Thus, the motive and force behind the two excavations differ greatly. In the case of Çatalhöyük, the motive can be found within archaeology as a high-profile, prestigious project, while the Malmö example is part of a large-scale project initiated by a political decision to build a (also prestigious) motorway around the city of Malmö.

So what are the prerequisites for reflexivity in two projects as different as these? I think the pressure in CRM archaeology by necessity makes the archaeologists very aware that prioritising is an urgent task, while in Çatalhöyük it is the methodology that is designed to achieve this. This difference may influence the way we reflect on prioritising. Thus, reflexivity is in this respect a part of CRM archaeology, but there is also a danger that time pressure will lead to unreflected decisions and routinisation. It is a very complex situation that does not always lead to reflexivity. An important factor is the control over which areas to investigate, as it has an impact on how well the questions can be answered. In CRM archaeology the builders' need of a certain area is a deciding factor and the questions asked will have to be based on that, while the research archaeologist can choose an object to investigate that best suits his or her questions.

Reflexivity is aided by discussion, and one difference between the two examples is the way in which discussion is formalised in Çatalhöyük, which is not the case in the Malmö example. In Çatalhöyük the discussion between excavating staff and specialists is facilitated by the system of work, while specialists are not present at the site in Malmö and the discussion takes place between the archaeologists. But is it the same kind of reflexivity in the two cases? The methodology at Catalhöyük explicitly aims at making the participants aware of their assumptions and preconceptions, while in the Malmö case the discussing and reasoning between the archaeologists lead to an awareness of why we are doing something and why in a certain way. So perhaps these 
are different kinds or levels of reflexivity?

Most decisions on the site in Malmö are taken after the discussions between archaeologists. Actually, the archaeologists in Malmö perform many of the tasks in post-excavation work which are done by the specialists in Çatalhöyük, for example analysing flint and pottery, which blurs the division between the two groups. This in turn leads to questioning of the two categories. Is it necessary to speak about specialists and excavators as two separate groups?

This explicit division between excavating staff and specialists in Çatalhöyük is in my experience what differs most from a Swedish situation. In both cases there are predecided issues and questions to be answered. In the example from Malmö the larger questions are decided by a project management and it is up to the archaeologists at the site to find the best ways to answer these questions. In Çatalhöyük much of the work is decided by the specialists' objectives. This has led to a hierarchical situation where the excavating archaeologist has less initiative.

This situation is perhaps not typical of British archaeology, but it certainly is, or has been, the situation at Çatalhöyük. So what is the cause of this hierarchical division? Does it only have practical reasons, or could there be an underlying assumption that archacological fieldwork is "just a handicraft" and not an intellectual process? Is the excavating archaeologist seen as a mere provider of information for someone else who will make the interpretation? Although this is exactly what the reflexive method is designed to counteract, it seems to be a very persistent idea that is difficult to avoid, also at Çatalhöyük. I suppose it goes back to the division between theory and practice, and it still is a great challenge for the archaeological discipline to bridge the gap between the two.

Is the notion that archaeological fieldwork is not an intellectual process, an issue in Sweden as well? To understand this problem, we have to return to the two separate traditions in archaeology: the archaeology initiated by academic research and the CRM archaeology. In Sweden the division between the two kinds of archaeology stems from an idea that research is a concern only for the academic archaeologists, and rescue archaeology is just that, a rescue mission to document information that otherwise would have been lost. The results were supposed to be mere "facts", objective and uninterpreted, and by publication made available to researchers at the universities.

In Malmö, for example, CRM archaeology was formed during a time when modernism had a great influence on society. Large developments took place in and around the city in the 1960 s and archaeological excavations became more frequent. Influenced by the same ideas, archaeology was modernised and was inspired by the natural sciences with quantifiability and objectivity as the main ideals (Magnusson Staaf 2000). CRM archaeology shared the same ideals as research archaeology but was left with the task of providing data for the researchers at the universities.

Academic training may also have played a role in keeping research and CRM archaeology apart. Archaeological education at the Swedish universities has traditionally not focused on preparing the student for fieldwork. Instead the emphasis is on knowledge of artefacts and archaeological cultures, combined with epistemology and the history 
of the archaeological discipline. The theoretical development is closely monitored and the post-processual theories have been an obvious part of the education for almost ten years, while the artefacts and the remains are still treated in traditional categories. Questions concerning how to bring research into CRM archaeology have not been directly addressed until very recently. The procedure that leads from the planning of a rescue project when an area is going to be developed, to the excavating process itself, and finally to the analysis and publication of the results, is not dealt with to any great extent; and questions important for fieldwork like research goals and priorities are only dealt with briefly. Fieldwork has not been seen as an integrated part of the education but as something that will come later, and as a matter of concern for the institutions engaged in CRM archaeology. Only a few weeks are spent in the field during the entire time of education. Until recently the excavating institutions could take on a few trainees every season in a sort of apprenticeship. But the situation in CRM archaeology has changed, and the increase in time pressure on fieldwork has led to greater demands on the staff. There is less time for training and newly employed archaeologists are expected to work independently almost from the start. A person who comes straight from the university is hardly prepared for that. It is worth noting that the guidelines from the Swedish National Heritage Board state that, in order to participate in an archaeological investigation, an archaeologist should have a BA in archaeology and three months of training in the field under an experienced supervisor (Riksantikvarieämbetet 1998:28).

Since the first half of the 1990s, the nature of research and rescue archaeology has been debated and an approach that combines the two has been strongly emphasised (Kyhlberg 1991; Lagerlöf 1991; Larsson \& Rudebeck 1993; Rudebeck 1996). It is worth noting that many of the persons active in this debate and also the proponents of a closer relationship, were both active in CRM archaeology and in research at the universities.

\section{PREREQUISITES OF REFLEXIVITY IN SWEDISH ARCHAEOLOGY?}

It has been suggested that Hodder's reflexive method is not completely his own invention, but rather part of a tradition of developing methods in British CRM archaeology, with roots in a processual rather than a post-processual tradition (Chadwick 1997; Hassan 1997). Leaving aside the question of who is the inventor of reflexivity in archaeology, Hodder is one of the first to try to formalise a reflexive method. Perhaps the need to reflect on what we are doing in archaeology is part of a larger discourse in society, and the reflexive method in Catalhöyük a part of that. At least there are signs of reflexivity in Swedish archaeology, even if it is not as explicit as at Catalhöyük.

As seen in the example of the excavation in Malmö, there is a tendency towards reflection in the normal work on a CRM excavation. The discussions between the archaeologists working on site create this reflexivity and perhaps it is not necessary to formalise these opportunities to discuss. The right conditions for reflexivity can be created anyway, by giving the archaeologists the responsibility of finding ways to answer research questions. A crucial point here is to allow time for reflection and to see it as a natural part of fieldwork. 
The Swedish National Heritage Board has required the institutions engaged in CRM archaeology to write research programs for their work, following a government bill of 1993/94. This bill stated that CRM archaeology should be part of a research process (Riksantikvarieämbetet 1998). This was a fundamental change from a few years earlier when the governmental research proposition of 1990 stated that all research funds should be given to the universities and not to the institutions engaged in CRM archaeology (Lagerlöf 1991). With this earlier proposition the government cemented the old view of a difference between research and CRM, which can probably be seen as representative of the view in society as a whole. But the situation changed just a few years later as a result of a general liberalisation in the Swedish society. In the middle of the 1990s the National Heritage Board ordered the excavating CRM institutions to write project plans and investigation programs for their activities. The project "Öresundsförbindelsen" in Malmö, of which the example in this article is a part, was one of the first projects to have such programs and plans. The bill of 1993/94 has been debated within the archaeological community, mainly regarding the consequences of prioritising different objects and the costs of excavations (Magnusson Staaf 2000:190). Work has begun, however, and the research programs have either just been issued or are currently being written in the different CRM institutions. The idea is that the programs should be flexible instruments and should be revised every couple of years. The programs tend to take a rather traditional starting point in their proposed research, for example the program for the Archaeological Excavations Department of the National Heritage Board, in the southern region (UV-Syd), which is focused on the traditional archaelogical periods. But in at least one of the research programs there is a tendency towards a more reflexive attitude, namely the research program of Malmö Cultural Resource Management (Malmö Kulturmiljö). According to this program, the archaeological work of the department will be guided by a number of themes. Among those are larger issues like 'continuity and discontinuity' and 'chronological complexity', which provide an opportunity to work without the usual temporal categories. The development of methods is also an important part of the program, for example concerning how to focus on anonymous materials and how to make the invisible visible. The investigation of topsoil is an example of this (Vetenskapligt program, Malmö Kulturmiljö).

Archaeology at the universities is facing a new challenge, in light of the changed conditions for CRM archaeology. Will the archaeological departments see it as their task to educate researchers for a career in CRM archaeology? University archaeology has recently started to change, and a greater influence from CRM archaeology is noticeable, for example the increasing number of persons from the CRM institutions who are engaged in planning and implementing academic training at the universities. There has also been a growing number of $\mathrm{PhD}$ students at the universities who have CRM archaeology as their professional base, not just as a means of earning a living. This situation has changed again however, as a government bill stated that $\mathrm{PhD}$ students as of 1998 shall have full funding within the university. The onset of the approach that combines the archaeology of universities and CRM institutions is therefore at risk. It is worth noting that the signals from the government and the authorities are not 
consistent, and their aim is perhaps simply to achieve a more efficient archaeology, not a more reflexive one.

\section{CONCLUDING REMARKS}

With this account of my personal experiences of the research project in Çatalhöyük and CRM archaeology in Sweden, have I answered the question of the possibilities of reflexivity? Is there a reflexive archaeology? In Çatalhöyük? In Sweden? I think the answer has to be 'yes'.

The project in Çatalhöyük has achieved the aim of producing reflexivity in the process of creating archaeological knowledge, but there have been obstacles along the way. The problems of achieving reflexivity seem to be caused by an unintended hierarchical division among the participants in the project, which is linked to an implicit assumption that archaeological fieldwork is not part of an intellectual process.

The reflexivity achieved in Swedish CRM archaeology seems to be unintended, at least in some respects. Many factors have worked together and the result is a degree of reflexivity in Swedish CRM archaeology. These factors include the directions formulated by the authorities and the government, the changes in society as a whole, but also factors from within the archaeological discipline such as the questioning of old structures, the influence of the theoretical debate and a general need of meaningful work.

In bridging the gap between theory and practice, between academic research and CRM archaeology, or between the desk and the trench, reflexivity is a key. If we take advantage of both the political situation, in which the govennment and the authorities demand archaeological results, and the debate within archaeology, I think we can look forward to a more reflexive archaeology in CRM in Sweden.

\section{English revised by Laura Wrang.}

\section{ACKNOWLEDGEMENTS}

I wish to thank all my colleagues in Burlöv during the hectic season of 1998 and at Çatalhöyük during the 1998 and 1999 seasons for good company and fruitfill discussions on methodology. And thanks to Ian Hodder for giving me the opportunity to participate in the excavation at Çatalhöyük. I also wish to thank Elisabeth Rudebeck and Kristina Jennbert for reading and giving very constructive comments on earlier versions of this text. 


\section{REFERENCES}

Berggren, $\AA .2000$. Contextual archaeology in theory and practice - some reflections on the excavations at Çatalhöyük. In: Eriksdotter, Larsson \& Löndahl (Eds). Att tolka stratigrafi. Det tredje nordiska stratigrafimötet, Aland 1999. Meddelanden från Ålands Högskola nr 11. Pp. 36-47.

Chadwick, A. 1997. Archaeology at the edge of chaos: further towards reflexive excavation methodologies. Assemblage Vol 3 (on line journal). http://www.shef.ac.uk/ assem $/ 3 / 3 \mathrm{chad} . \mathrm{htm}$

Farid, S. 2000. The excavation process at Çatalhöyük. In: Hodder, H. (Ed). Towards reflexive method in archaeology: the example at Çatalhöyük. Pp. 19-35. BIAA Monograph. Cambridge.

Hassan, F. 1997. Beyond the surface: comments on Hodder's 'reflexive excavation methodology'. Antiquity 7I. Pp. 1020-1025.

Hodder, I. 1997. 'Always momentary, fluid and flexible': towards a reflexible excavation methodology. Antiquity 71. Pp. 691-700.

- 1999. The archaeological process: an introduction. Oxford.

Hodder, I. (Ed). 2000. Towards reflexive method in archaeology: the example at Çatalhöyïk. BIAA Monograph. Cambridge.

Kyhlberg, O. 1991. Arkeologisk uppdragsverksamhet. Perspektiv på 90-talet. Kulturmiljövård 2:9I. Pp. 11 14.

Lagerlöf, A. 1991. FoU inom den arkeologiska kulturmiljövården. Kulturmiljövård 2:91. Pp. 15-19.

Larsson, S. \& Rudebeck, E. 1993. Arkeologin och makten över meningen. META 93:1. Pp. 3-19.

Magnusson Staaf, B. 2000. The rise and decline (?) of the modern in Sweden. Reflected through Cultural Resource Management Archaeology. Current Swedish Archaeology, Vol 8. Pp. 179-194.

Riksantikvarieämbetet, (Raä) 1998. Uppdragsarkeologi. Rekommendationer vid upprättande av undersökningsplaner mm. Underrättelser från RAÄ.

Rudebeck, E. 1996. Expectations on Swedish rescue archaeology: Fertile circles, the courage not to know and texts with meaning. Current Swedish Archaeology, Vol 4. Pp. 165-170.

Vetenskapligt program för UV-Syd 1999-2002. Ed: Hansson. Riksantikvarieämbetet, Avdelningen för arkeologiska undersökningar. Rapport UV-Syd 1999:35.

Vetenskapligt program (in preparation). (Eds). Rudebeck \& Ödman. Malmö Kulturmiljö. 